\title{
Dystocia in Friesian cows and its effects on postpartum reproductive performance and milk production
}

\author{
H. M. A. Gaafar • Sh. M. Shamiah • \\ M. A. Abu El-Hamd • A. A. Shitta • M. A. Tag El-Din
}

Accepted: 5 August 2010 /Published online: 11 September 2010

(C) The Author(s) 2010. This article is published with open access at Springerlink.com

\begin{abstract}
A total of 1,243 records for 585 dairy Friesian cows from 1997-2004 were used to study the factors affecting dystocia and its effects on reproductive performance and milk production. The overall incidence of dystocia was $6.9 \%$. The percentage of dystocia decreased with increasing live body weight, age, and parity of cows $(P<0.05)$; however, it increased with increasing birth weight of calves $(P<0.05)$. The highest percentage of dystocia was detected in winter season, but the least percentage was in summer season $(P<0.05)$. The percentage of incidence of dystocia was significantly $(P<0.05)$ higher with winter feeding compared to summer ration $(8.2 \%$ vs. $5.1 \%)$. The percentage of incidence of dystocia was significantly $(P<0.05)$ higher with twinning than single calving $(15.5 \%$ vs. $6.5 \%)$, while not significantly affected by the sex of born calves. Incidence of dystocia had adverse effects on reproductive performance and milk yield. The service interval, service period, days open, and calving interval were significantly $(P<0.05)$ longer in cows afflicted with dystocia compared to normal cows. The conception rate was lower $(P<0.05)$, but the number of service per conception was higher $(P<0.05)$ in cows afflicted with dystocia compared to normal cows $(60.5 \%$ vs. $73.0 \%$ and 3.4 vs. 2.7 , respectively). Average daily milk yield was lower $(P<0.05)$ by $1 \mathrm{~kg}$ for cows with incidence of dystocia compared to normal cows.
\end{abstract}

H. M. A. Gaafar $(\bowtie) \cdot$ S. M. Shamiah • M. A. A. El-Hamd •

A. A. Shitta • M. A. T. El-Din

Animal Production Research Institute,

Agricultural Research Center,

Nadi El-Said Street, Dokki,

Giza, Egypt

e-mail: gaafar356@hotmail.com
Keywords Friesian cows · Dystocia .

Reproductive performance $\cdot$ Milk production

\section{Introduction}

The various factors affecting dystocia in cattle are grouped into four main categories: direct factors, phenotypic factors related to calf and cow, non-genetic and genetic factors. The first group includes malpresentations and uterine torsion. The second one includes: calf birth weight, multiple calvings, perinatal mortality, cow pelvic area, cow body weight, and body condition at calving, and gestation length. The non-genetic factors are: cow age and parity, year and season of calving, place of calving, maintenance practices, disorders, and calf sex and nutrition (Zaborski et al. 2009). In general, dystocia occurs when the size of the fetus is incompatible with the size of the pelvic opening of the cow, when the fetus is abnormally presented (breeched, head, or foot back), or when the cow does not experience normal parturition due to weakness, stress, or hormonal abnormalities. However, many other factors may also influence the incidence of dystocia, and these factors can be split into two categories: factors affecting the size and shape of the calf and factors affecting the ability of the dam to give birth (Roughsedge and Dwyer 2006). Nongenetic factors affecting the risk of dystocia include year, time of year at calving, dam parity (Meyer et al. 2001; Johanson and Berger 2003; Steinbock et al. 2003), herd (Steinbock et al. 2003), age at calving within parity (Ettema and Santos 2004), sex of calf (Johanson and Berger 2003; Ettema and Santos 2004), calf birth weight (Johanson and Berger 2003), gestation length (Meyer et al. 2001; Johanson and Berger 2003), and whether the calf was a singleton or twin (Ettema and Santos 2004). Factors affecting the 
incidence of dystocia were parity of dam, sex of calf, whether the calf was a singleton or twin, and a linear regression on the weight of the calf (Berry et al. 2007). Several studies have implicated dystocia as a contributing factor to reduced milk yield (Berry et al. 2007) and poorer fertility (Lopez de Maturana et al. 2007). The objective of this study was to investigate some factors affecting the incidence of dystocia and its effects on reproductive performance and milk yield in dairy Friesian cows.

\section{Materials and methods}

Experimental animals

A total of 1,243 records for 585 dairy Friesian cows from 1997-2004 were collected from Sakha Animal Production Research Station belonging to Animal Production Research Institute, Agricultural Research Center, Ministry of Agriculture, Egypt. All cows ranged between $350-650 \mathrm{~kg}$ live weight, 3-13 years of age, and 1-8 parities.

Feeding and management

Animals were housed in semi-opened sheds and fed traditional summer ration consisting of concentrate feed mixture, berseem hay, rice straw with or without corn silage and traditional winter ration consisting of concentrate feed mixture, fresh berseem, and rice straw. Cows were fed to cover the recommended requirements according to Animal Production Research Institute Recommendation (1997) in group feeding assigned according to live body weight, milk yield, and reproductive status. Cows were artificially inseminated using frozen semen within $14 \mathrm{~h}$ after onset of the first spontaneously occurring estrus.

\section{Collected data}

The collected data included live body weight and age of dams, parity, calving season, type of birth, sex of born calf, and type of feeding for the different years. Also, data were collected for the periods from parturition to first service, conception service, days open, gestation period, calving interval, number of services per conception, conception rate, total milk yield, and lactation period.

\section{Ambient temperature}

The average air temperature ranged from $20^{\circ} \mathrm{C}$ at day to $10^{\circ} \mathrm{C}$ at night during winter season and $35^{\circ} \mathrm{C}$ at day to $23^{\circ} \mathrm{C}$ at night during summer season.
Statistical analysis

The obtained data were statistically analyzed using factorial design procedure adapted by SPSS (2008) for user's guide. Duncan test within program SPSS was done to determine the degree of significance among means.

\section{Results and discussion}

Of the 1,243 births studied, 86 were afflicted with dystocia $(6.9 \%)$, which was nearly similar to the figure in cows being $7 \%$ as presented by Berry et al. (2007), but was higher than the reported dystocia rates in dairy cattle internationally being $<5 \%$ (Mee 2008).

Some factors affecting the incidence of dystocia

Live body weight of cows

The percentage of dystocia decreased significantly $(P<$ 0.05 ) with increasing live body weight of cows, which ranged from $5.3 \%$ for cows that weighed $600-650 \mathrm{~kg}$ to $8.3 \%$ for cows that weighed $350-400 \mathrm{~kg}$ (Table 1). These results are in accordance with those obtained by Anderson (1992) who found high negative correlation between dam weight and the incidence of dystocia.

\section{Age of dam}

The percentage of incidence of dystocia in Friesian cows decreased significantly $(P<0.05)$ with age progression, which decreased from $7.4 \%$ at $3-5$ years of age to $4.6 \%$ at 11-13 years as shown in Table 1. These results agreed with those obtained by Roughsedge and Dwyer (2006) who found that first-calf heifers account for the majority of calving difficulties and associated calf losses. High rates of dystocia among first-calf heifers and young cows are mostly due to their smaller size at first parturition than at subsequent calvings.

\section{Number of parity}

Results in Table 1 revealed that the effect of parity on the percentage of dystocia in Friesian cows showed similar trend to age of cows, which decreased significantly $(P<$ 0.05 ) from $7.7-4.6 \%$ with advancing parity from 1 st to 8 th parity. These results are in accordance with those obtained by Eriksson et al. (2004) who found that the frequencies of difficult calvings and stillbirths were approximately $6 \%$ at first parity and $1-2 \%$ at later parities for Charolais and Hereford cattle. 
Table 1 Effect of body weight, age and parity of Friesian cows on the percentage of dystocia

\begin{tabular}{|c|c|c|c|}
\hline Item & No. of records & No. of dystocia & Dystocia rate $\%$ \\
\hline \multicolumn{4}{|l|}{ Cow weight } \\
\hline $350-400 \mathrm{~kg}$ & 48 & 4 & $8.3 \mathrm{a}$ \\
\hline $400-450 \mathrm{~kg}$ & 150 & 12 & $8.0 \mathrm{a}, \mathrm{b}$ \\
\hline $450-500 \mathrm{~kg}$ & 426 & 31 & $7.3 \mathrm{a}, \mathrm{b}$ \\
\hline $500-550 \mathrm{~kg}$ & 394 & 26 & $6.6 \mathrm{a}, \mathrm{b}$ \\
\hline $550-600 \mathrm{~kg}$ & 150 & 9 & $6.0 \mathrm{a}, \mathrm{b}$ \\
\hline $600-650 \mathrm{~kg}$ & 75 & 4 & $5.3 \mathrm{~b}$ \\
\hline \multicolumn{4}{|l|}{ Cow age } \\
\hline 3-5 year & 706 & 52 & $7.4 \mathrm{a}$ \\
\hline 5-7 year & 302 & 21 & $7.0 \mathrm{a}, \mathrm{b}$ \\
\hline $7-9$ year & 177 & 10 & $5.7 \mathrm{a}, \mathrm{b}$ \\
\hline $9-11$ year & 36 & 2 & $5.6 \mathrm{a}, \mathrm{b}$ \\
\hline $11-13$ year & 22 & 1 & $4.6 \mathrm{~b}$ \\
\hline \multicolumn{4}{|l|}{ Parity } \\
\hline 1 & 402 & 31 & $7.7 \mathrm{a}$ \\
\hline 2 & 304 & 22 & $7.2 \mathrm{a}, \mathrm{b}$ \\
\hline 3 & 194 & 13 & $6.7 \mathrm{a}, \mathrm{b}$ \\
\hline 4 & 108 & 7 & $6.5 \mathrm{a}, \mathrm{b}$ \\
\hline 5 & 88 & 5 & $5.7 \mathrm{a}, \mathrm{b}$ \\
\hline 6 & 89 & 5 & $5.6 \mathrm{a}, \mathrm{b}$ \\
\hline 7 & 36 & 2 & $5.6 \mathrm{a}, \mathrm{b}$ \\
\hline 8 & 22 & 1 & $4.6 \mathrm{~b}$ \\
\hline Overall mean & 1,243 & 86 & 6.9 \\
\hline
\end{tabular}

Means in the same column with different lowercase letters differ significantly $(P<0.05)$ the incidence of dystocia attributable to malpresentation. Echternkamp et al. (2007) found increased incidence of dystocia for twin or triplet births compared with single births.

\section{Calf sex}

The percentages of incidence of dystocia in Friesian cows tended to be higher with born male than female calves
Table 2 Effect of type of birth, sex, and birth weight of calves on the percentage of dystocia in Friesian cows

\begin{tabular}{lccc}
\hline Item & No. of records & No. of dystocia & Dystocia rate \% \\
\hline Type of birth & & 77 & \\
Single & 1,185 & 9 & $6.5 \mathrm{~b}$ \\
Twining & 58 & & $15.5 \mathrm{a}$ \\
Calf sex & 623 & 46 & 7.4 \\
Male & 620 & 40 & 6.5 \\
Female & & & \\
Calf birth weight & 44 & 2 & $4.6 \mathrm{~b}$ \\
$>20 \mathrm{~kg}$ & 157 & 9 & $5.7 \mathrm{a}, \mathrm{b}$ \\
$21-25 \mathrm{~kg}$ & 312 & 19 & $6.1 \mathrm{a}, \mathrm{b}$ \\
$26-30 \mathrm{~kg}$ & 363 & 26 & $7.2 \mathrm{a}, \mathrm{b}$ \\
$31-35 \mathrm{~kg}$ & 308 & 25 & $8.1 \mathrm{a}, \mathrm{b}$ \\
$36-40 \mathrm{~kg}$ & 59 & 5 & $8.5 \mathrm{a}$ \\
$<40 \mathrm{~kg}$ & 1,243 & 86 & 6.9 \\
Overall mean & & & \\
\hline
\end{tabular}

Means in the same column with different lowercase letters differ significantly $(P<0.05)$ 
Table 3 Effect of calving year and season and feeding system on the percentage of dystocia in Friesian cows
Means in the same column with different lowercase letters differ significantly $(P<0.05)$

\begin{tabular}{lrcc}
\hline Item & No. of records & No. of dystocia & Dystocia rate \% \\
\hline Calving year & 148 & 10 & 6.8 \\
1997 & 95 & 7 & 7.4 \\
1998 & 92 & 6 & 6.5 \\
1999 & 203 & 15 & 7.4 \\
2000 & 169 & 12 & 7.1 \\
2001 & 227 & 14 & 6.2 \\
2002 & 175 & 13 & 7.4 \\
2003 & 134 & 9 & 6.7 \\
2004 & & & $8.5 \mathrm{a}$ \\
Calving season & 425 & 36 & $7.7 \mathrm{a}, \mathrm{b}$ \\
Winter & 311 & 24 & $4.8 \mathrm{~b}$ \\
Spring & 249 & 12 & $5.4 \mathrm{a}, \mathrm{b}$ \\
Summer & 258 & 14 & $8.2 \mathrm{a}$ \\
Autumn & & & $5.1 \mathrm{~b}$ \\
Feeding system & 736 & 60 & 6.9 \\
Winter ration & 507 & 26 & 86 \\
Summer ration & 1,243 & & \\
Overall mean & & & \\
\hline
\end{tabular}

(7.8\% vs. $6.5 \%)$ as shown in Table 2 . These results are in agreement with those obtained by Johanson and Berger (2003) and Ettema and Santos (2004) who found that calf sex affected the incidence of dystocia, and it was higher in males than in females.

\section{Calf birth weight}

The percentage of incidence of dystocia increased significantly $(P<0.05)$ with increasing birth weight of born calves (Table 2). Calf birth weight is the trait most highly correlated with incidence of dystocia (Anderson 1992).

\section{Year of calving}

The percentage of incidence of dystocia was not significantly $(P>0.05)$ different among the different years of study and ranged from $6.2-7.4 \%$, with an average of $6.9 \%$, as shown in Table 3. These values are higher than the reported dystocia rates in dairy cattle internationally, which are generally $<5 \%$ (Mee 2008). Year of calving affected the incidence of dystocia (Zaborski et al. 2009).

\section{Calving season}

The highest percentage $(P<0.05)$ of incidence of dystocia was detected in winter season $(8.5 \%)$, while the least percentage $(P<0.05)$ was noticed in summer season $(4.8 \%)$ as shown in Table 3 . These results agreed with those obtained by season of calving internationally, which are generally $<5 \%$ (Mee 2008). Colburn et al. (1997) suggested that greater calf birth weight and calving difficulty may be expected in winter following severe spring temperatures.

\section{Feeding system}

Results in Table 3 revealed that the percentage of incidence of dystocia in Friesian cows was significantly $(P<0.05)$ higher with feeding winter ration compared with summer ration $(8.2 \%$ vs. $5.1 \%)$. These results are in accordance with

Table 4 Effect of dystocia on reproductive performance and milk production of Friesian cows

\begin{tabular}{|c|c|c|c|}
\hline Item & Normal & Dystocia & SEM \\
\hline No. of cows & 1,157 & 86 & \\
\hline \multicolumn{4}{|l|}{ Reproductive intervals (day) } \\
\hline - First estrus & $22 \mathrm{~b}$ & $26 \mathrm{a}$ & 0.2 \\
\hline - First service & $49 \mathrm{~b}$ & $58 \mathrm{a}$ & 0.5 \\
\hline - Service period & $74 \mathrm{~b}$ & 92 a & 2.6 \\
\hline - Days open (day) & $123 \mathrm{~b}$ & $151 \mathrm{a}$ & 2.8 \\
\hline - Gestation period & 277 & 278 & 0.2 \\
\hline - Calving interval & $401 \mathrm{~b}$ & 429 a & 2.8 \\
\hline Conception rate $\%$ & $73.0 \mathrm{a}$ & $60.5 \mathrm{~b}$ & 1.3 \\
\hline No. of service per conception & $2.7 \mathrm{~b}$ & $3.4 \mathrm{a}$ & 0.1 \\
\hline Milk production (kg/day) & $12.8 \mathrm{a}$ & $11.8 \mathrm{~b}$ & 0.1 \\
\hline
\end{tabular}

Means in the same column with different lowercase letters differ significantly $(P<0.05)$ 
those obtained by Zaborski et al. (2009) who found that nutrition had an effect on dystocia. Manipulating feeding level during pregnancy offers an alternative method for manipulating the birth weight of calves. Little is known about the effects of nutrition in early gestation on placental development or birth weight of calves (Hickson et al. 2006).

Effect of dystocia on reproductive performance of Friesian cows

\section{Reproductive intervals}

The incidence of dystocia had an adverse effect on the reproductive performance of dairy Friesian cows as shown in Table 4. The first estrus, first service, service period, days open and calving interval were significantly longer $(P<0.05)$ in cows that exhibited dystocia compared to normal cows $(58.1,92.5,150.5$, and 428.5 vs. 49.2, 74.0, 123.2 and 400.6 day, respectively). However, gestation period was nearly similar for normal and cows that exhibited dystocia. These results indicated that dystocia led to increasing the service interval, service period, days open and calving interval by $8.9,18.5,27.3$, and 28.0 day, respectively. These results are in agreement with those obtained by Lopez de Maturana et al. (2007) who reported that the effect of dystocia was statistically significant, implying a delay in the pregnancy periods of the cow.

\section{Conception rate}

The incidence of dystocia resulted in a significant $(P<0.05)$ reduction in conception rate, where the conception rate at 90,120 , and 150 days, and the entire lactation for cows that exhibited dystocia reduced by $10.7 \%, 11.5 \%, 12.02 \%$, and $12.5 \%$ compared with normal cows, respectively. These results are in accordance with those obtained by Lopez de Maturana et al. (2007) who showed that dystocia resulted in impaired fertility because it decreased the incidence of success at first insemination by $12 \%$.

\section{Number of service per conception}

The number of service per conception for cows exhibited that dystocia was significantly higher $(P<0.05)$ compared to normal cows (3.4 vs. 2.7). These results might be due to the lower conception rate as well as the longer service period for cows that exhibited dystocia. These results agreed with those obtained by Lopez de Maturana et al. (2007) who found that the effect of dystocia was statistically significant. This fact indicates that 0.5 more inseminations are needed to impregnate the cow in the next reproductive cycle after a difficult calving.
Effect of dystocia on milk production

Data in Table 4 showed that lactation period was significantly longer $(P<0.05)$, while average daily milk yield was significantly lower $(P<0.05)$ for cows with incidence of dystocia compared to normal cows. However, total milk yield tended to lower for cows with incidence of dystocia compared to normal cows. These might be due to the longer days for cows with incidence of dystocia. These results are in accordance with those obtained by Berry et al. (2007) who found that milk yield was less in cows that experienced dystocia at calving compared with those that did not.

\section{Conclusion}

Causes of dystocia are complex because many factors are interrelated, and methods to reduce dystocia are complicated. Dystocia adversely affects reproductive performance and milk yield of Friesian cows.

Open Access This article is distributed under the terms of the Creative Commons Attribution Noncommercial License which permits any noncommercial use, distribution, and reproduction in any medium, provided the original author(s) and source are credited.

\section{References}

Anderson, P., 1992. Minimizing calving difficulty in beef cattle. http:// www.thebeefsite.com/articles/658/minimizing-calving-difficultyin-beef-cattle

Animal Production Research Institute, 1997. Animal Nutrition Scientifically and Practically. 1st Ed. Animal Production Research Institute, Agricultural Research Center, Ministry of Agriculture, Dokki, Giza, Egypt (In Arabic), ISBN 3160/98.

Berry, D.P., Lee, J.M., Macdonald, K.A. and Roche, J.R., 2007. Body condition score and body weight effects on dystocia and stillbirths and consequent effects on postcalving performance. Journal of Dairy Science, 90, 4201-4211, http://jds.fass.org/cgi/ reprint/90/9/4201

Colburn, D.J., Deutscher, G.H., Nielsen, M.K. and Adams, D.C., 1997. Effects of sire, dam traits, calf traits, and environment on dystocia and subsequent reproduction of two-year-old heifers. Journal of Animal Science, 75, 1452-1460, http://jas.fass.org/cgi/ reprint $/ 75 / 6 / 1452$

Echternkamp, S.E., Thallman, R.M., Cushman, R.A., Allan, M.F. and Gregory, K.E., 2007. Increased calf production in cattle selected for twin ovulations. Journal of Animal Science, 85, 3239-3248, http://jas.fass.org/cgi/reprint/85/12/3239

Eriksson, S., Nasholm, A., Johansson, K. and Philipsson, J., 2004. Genetic parameters for calving difficulty, stillbirth, and birth weight for Hereford and Charolais at first and later parities. Journal of Animal Science, 82, 375-383, http://jas.fass.org/cgi/ reprint $/ 82 / 2 / 375$

Ettema, J.F. and Santos, J.E.P., 2004. Impact of age at calving on lactation, reproduction, health, and income in first-parity Hol- 
steins on commercial farms. Journal of Dairy Science, 87, 2730 2742, http://jds.fass.org/cgi/reprint/87/8/2730

Hickson, R.E., Morris, S.T., Kenyon, P.R. and Lopez-Villalobos, N., 2006. Dystocia in beef heifers: a review of genetic and nutritional influences. New Zealand Veterinary Journal, 54, 256-264.

Johanson, J.M. and Berger, P.J., 2003. Birth weight as a predictor of calving ease and perinatal mortality in Holstein cattle. Journal of Dairy Science, 86, 3745-3755, http://jds.fass.org/cgi/reprint/86/11/3745

Kirkpatrick, B.W., 2002. Management of twinning cow herds. Journal of Animal Science, 80, E14-E18, http://jas.fass.org/cgi/reprint/ 80/E-Suppl_2/E14

Lopez de Maturana, E., Legarra, A., Varona, L. and Ugarte, E., 2007. Analysis of Fertility and Dystocia in Holsteins Using Recursive Models to Handle Censored and Categorical Data. Journal of Dairy Science, 90, 2012-2024, http://jds.fass.org/cgi/reprint/90/ $4 / 2012$

Mee, J.F., 2008. Prevalence and risk factors for dystocia in dairy cattle: A review. The Veterinary Journal, 176, 93-101.
Meyer, C.L., Berger, P.J., Koehler, K.J., Thompson, J.R. and Sattler, C.G., 2001. Phenotypic trends in incidence of stillbirth for Holsteins in the United States. Journal of Dairy Science, 84, 515523, http://jds.fass.org/cgi/reprint/84/2/515

Roughsedge, T. and Dwyer, C., 2006. Factors affecting the ability of the dam to give birth. http:/www.sac.ac.uk/research/themes/ animalhealth/animalhealthwelfare/beef/difficultcalving/causesdystocia/dambirth

SPSS for windows, 2008. Statistical package for the social sciences, Release: 16, (SPSS INC, Chicago, USA)

Steinbock, L., Nasholm, A., Berglund, B., Johansson, K. and Philipsson, J., 2003. Genetic effects of stillbirth and calving difficulty in Swedish Holsteins at first and second calving. Journal of Dairy Science, 86, 2228-2235, http://jds.fass.org/cgi/ reprint $/ 86 / 6 / 2228$

Zaborski, D., Grzesiak, W., Szatkowska, I., Dybus, A., Muszynska, M. and Jedrzejczak, M., 2009. Factors affecting dystocia in cattle. Reproduction in Domestic Animals, 44, 540-551. 